\title{
The Striking Similarities between Northern Norway and Northern Sweden
}

\author{
Jonas Stein \\ UiT The Arctic University of Norway
}

\begin{abstract}
Contrary to the view held by many actors, this paper, by using a quantitative and longitudinal analysis in a comparative perspective, show that demographic development in Northern Norway and Northern Sweden is much more similar than many think. Over the last 60 years, there has been a small negative trend in the relative percentage of the national population that lives in the two regions, with "knowledge cities", and especially the two university cities Tromsø and Umeå, as the exception. Despite Broxian social theories of regional development in Northern Norway and the implementation of a generous set of regional policies, there seems to be no cause to claim that Northern Norway has followed a unique path of development compared to Northern Sweden, neither in general nor in smaller and more rural communities.
\end{abstract}

Keywords: regional policy, Arctic, Northern Norway, university, municipalities

Responsible Editor: Øyvind Ravna, UiT - The Arctic University of Norway, Tromsø, Norway

Received: April 2018; Accepted: March 2019; Published: March 2019

\section{Introduction}

Many politicians ${ }^{1}$, scholars ${ }^{2}$ and regional actors have proclaimed that Norway's regional policies in Northern Norway have succeeded extremely well. Since the mid-1970s Norwegian authorities have implemented generous policies for regional

1 Kjell Werner, "Helga satser på by og land," FriFagbevegelse, https://frifagbevegelse.no/ article-6.158.52638.bdb95fa104.

2 Ottar Brox, Hva skjer i Nord-Norge? (Oslo: Pax Forl., 1966).

\footnotetext{
^Correspondence to: Jonas Stein, email: jonas.stein@uit.no

(C) 2019 Jonas Stein. This is an Open Access article distributed under the terms of the Creative Commons Attribution-NonCommercial 4.0 International License (https://creativecommons.org/licenses/by-nc/4.0/), allowing third parties to share their work (copy, distribute, transmit) and to adapt it, under the condition that the authors are given credit, that the work is not used for commercial purposes, and that in the event of reuse or distribution, the terms of this license are made clear. Citation: Fonas Stein. "The Striking Similarities between Northern Norway and Northern Sweden" Arctic Review on Law and Politics,Vol. 10, 2019, pp. 79-102. http://dx.doi.org/10.23865/arctic.v10.1247
} 
development aimed at maintaining a dispersed population in Northern Norway. Of interest in this paper is to assess the aims of these different policies and their actual effect on regional development. In 2016 the Norwegian government spent around 12 billion NOK on specific policies aimed at regional development in Northern Norway (Finnmark, Troms and Nordland counties). In comparison, Sweden through European Union structural funds, spent around 0.3 billion NOK on regional development in Northern Sweden (Västerbotten and Norrbotten counties). Norway and Sweden share a multitude of common social, cultural and political factors, making a most similar case design comparison a fruitful methodological approach.

The idea of a unique path for Northern Norway is rooted in the ideas of Ottar Brox. ${ }^{3}$ His early works on Northern Norway are considered some of the most important works of nonfiction in Norway since $1945 .{ }^{4}$ They have heavily influenced policymaking in Northern Norway, resulting in important differences in those policies geared toward regional development and those promoting dispersed settlement in the north. There are many structural similarities between Northern Norway and Northern Sweden. At the regional level, there are important similarities, like the establishment of universities in the North and similar universal welfare systems administered at the municipal level.

However, there are also some important differences in regional policies between Norway and Sweden, and according to Broxian theories, these differences should have led to more positive development in Northern Norway. First, the Norwegian people chose to stay outside the European Union twice; national referendums were held in 1972 and 1994. A major factor for voters was to maintain national sovereignty over policies for regional development. ${ }^{5}$ Second, Norway has implemented regional policies that include regionally differentiated payroll taxes on employees, with an extra contribution for municipalities in Northern Norway ${ }^{6}$ and individual level tax cuts for people living in the special zone. Third, Norway has also chosen to maintain a large number of small municipalities compared to Sweden. These differences have led Norwegian politicians, including two former ministers, Trygve Slagsvold Vedum ${ }^{7}$ and Helga Pedersen, ${ }^{8}$ to claim that Norway, through its regional policies, has been much more successful in keeping a dispersed population structure than its neighboring countries, especially in the High North. The question is; is there cause to claim that Northern Norway has followed a unique development path compared to Northern Sweden?

3 Ibid.; Nord-Norge: Fra allmenning til koloni (Oslo: Universitetsforlaget, 1984).

4 Morten Strøksnes, "Nordlands profet," Dagbladet, 30.07. 2008.

5 Henry Valen, "Norway: 'No' to EEC," Scandinavian Political Studies 8, no. A8 (1973).

6 Erik Oddvar Eriksen, "Det nye Nord-Norge: avhengighet og modernisering i nord," in Avhengighet og modernisering i nord, ed. Erik Oddvar Eriksen (Bergen: Fagbokforlaget, 1996).

7 Trygve Slagsvold Vedum, “Sentraliseringen er blåkopi,” Nationen, 12.08.20152015.

8 Werner, "Helga satser på by og land". 
Even though Brox's theories have had massive importance theoretically and politically, they have not been tested empirically. This paper will argue that a quantitative comparison of Northern Norway and Northern Sweden does not bring forth any arguments that support the claim that Norway has followed a unique path of development in the Arctic region. On the contrary, the similarities between the two regions are striking. First, I will review the theoretical and empirical arguments for Norwegian regional policies and alternative theories of regional development. Afterward I will account for the quantitative methodological approach used in this study. Finally, the empirical results will be analyzed and discussed.

\section{Theoretical framework}

\subsection{Center-peripheral relationship in the North and opposition to EU membership} Both Northern Norway and Northern Sweden exist within what Stein Rokkan ${ }^{9}$ would describe as a center-peripheral relationship, which is important to understand policy development. Combining the organizational decision-making system of Hirschman, ${ }^{10}$ and Talcott Parson's paradigm for functional differentiation within states, ${ }^{11}$ Rokkan provides a general and theoretical model for solving the relationship between the center and the territorial periphery within the state. The theoretical salience of the center-periphery axis is that the existence of a political center logically presupposes a periphery - and vice versa. The two are interdependent.

Because any collective distinction may serve as the underpinning for political mobilization $^{12}$ differing historiographies may create territorially different political identities. Hence, political actors that perceive themselves as representatives of "peripheries" tend to nurture the idea that different identities linked to territories have developed over time. Some geographical identity is thus an asset in the regional political mobilization against the state's centralizing efforts. Whether regional actors choose and succeed in mobilizing on a territorial basis will largely depend on the status of the region vis-à-vis the state during the various phases in the modernization process. Throughout the nation-building process, the periphery is left with three choices that regional actors can mobilize upon; exit, voice or loyalty.

9 Stein Rokkan, Stat, Nasjon, Klasse (Oslo: Universitetsforlaget, 1987); State Formation, Nation-Building, and Mass Politics in Europe:The Theory of Stein Rokkan: Based on His Collected Works (Clarendon Press, 1999); Stein Rokkan and Derek W. Urwin, Economy, Territory, Identity: Politics of West European Peripheries (London: Sage Publications, 1983).

10 Albert Hirschman, "Exit, Voice, and Loyalty," Cambridge, MA: Harvard University Press (1970).

11 Talcott Parsons, "On the Concept of Political Power," Proceedings of the American Philosophical Society 107, no. 3 (1963).

12 Giovanni Sartori, “The Sociology of Parties," in The West European Party System, ed. Peter Mair (Oxford: Oxford University Press on Demand, 1990). 
Exit, which entails the creation of a more or less independent regional state, has never been a real option in either Northern Norway or Northern Sweden. However, through protests (voice) or making deals with the central government (loyalty) some regional concessions have been made, especially in Norway. The reasons for regional policies have to be understood within the context of a center-peripheral relationship. However, achieving concessions sometimes turns out to be a double-edged sword. Departing from the Wilsonian concept of Clientelism, ${ }^{13}$ Eriksen develops the notion of state dependency; the region occupies a clientele position towards the central government, and adopts a clientelist perspective. This perspective confines the regional actors' scope for alternative political action, and instead, their focus is on existing programs and subsidies as the only possible way forward. ${ }^{14}$

Rokkan and other scholars identified Northern Norway as a peripheral region that was considered backward and less developed by the central authorities. ${ }^{15}$ Norway implemented a number of regional policies throughout the post-war era, to stimulate regional development in Northern Norway. In the early 1950s, the Labor Party government created a development plan for Northern Norway based on industrialization and macro-economic principles. ${ }^{16}$ These principles for social and economic development were later challenged by the theories of Ottar Brox ${ }^{17}$ who emphasized the relative wealth of the fisher-farmer lifestyle in the rural parts of Northern Norway, explaining why life in small peripheral communities is a rational choice for people. Due to the Norwegian geography with its long coastline, the fisher-farmer could live in small rural villages supporting himself mostly by harvesting from nature. He could stay self-sufficient outside the monetary economy. According to Brox, the relative wealth of the fisher-farmer was the reason that people did not move to industrial cities and chose instead to remain in rural settlements. This combination was unique for the coastal areas of Northern Norway and was the basis for the idea of a unique situation in Northern Norway where urbanization and industrialization were not seen as a necessity, but as something that could be rejected by the people. Implicit in the Broxian theories we find the idea that given a choice, people will choose a rural lifestyle and reject urbanization and industrialization.

13 James Wilson, Bureaucracy: What Government Agencies Do and Why They Do It (New York: Basic Books, 1989).

14 Eriksen, "Det nye Nord-Norge: Avhengighet og modernisering i nord."

15 O. Grønaas, J. Halvorsen, and L. Torgersen, "Problemet Nord-Norge," Studieselskapet for nordnorsk neringsliv. (1948).

16 Kjell Arne Røvik, Jens-Ivar Nergård, and Svein Jentoft, Hvor går Nord-Norge? (Stamsund: Orkana akademisk, 2011).

17 Brox, Hva skjer $i$ Nord-Norge? 
Brox's theories have had a major impact on political ideology in Norway, with ecological awareness being seen as a counterweight to industrialization and globalization, ${ }^{18}$ ideas primarily associated with the powerful Labor party. ${ }^{19}$ In addition to contributing to the Labor Party's rural development policies, ${ }^{20}$ Brox's theories also provided a framework for the radical left in the 1970s and underpinned the mobilization of the winning coalition against Norwegian membership in the EEC in 1972, a coalition that combined urban radical leftists with the peripheral interests of fisher-farmers. ${ }^{21}$ In the Norwegian referendums on EEC membership in 1972 and EU membership in 1994, opposition was particularly strong in peripheral areas, particularly in Northern Norway. Excluding the no-votes in Northern Norway (Nordland, Troms, and Finnmark counties) there would have been a small majority (50.2 percent) in the rest of the country for Norwegian EU membership in 1994. In Northern Sweden (Västerbotten and Norrbotten), we find the same pattern of opposition against joining the European Union. In the EU referendum in 1994, 64 percent of voters in Northern Sweden voted against EU membership. ${ }^{22} 72$ percent of voters in Northern Norway voted against. ${ }^{23}$ The main difference, however, was the outcome of the national referendum. A majority of Swedish voters opted for EU membership, but Norway voted to remain outside.

\subsection{Differentiated tax roll and other subsidies}

In the aftermath of the Norwegian EEC referendum in 1972, when a periphery-led opposition against Norwegian membership won the referendum, the pro-EEC Labor party lost heavily in the next general election, especially in the periphery. Subsequently, the Labor party changed its rhetoric and goals for regional development. When the Labor party regained strength in the 1977 parliamentary election, they did so in a broader alliance with peripheral regions, changing the official Norwegian policy to "maintain the fundamental features of the population distribution" ${ }^{24}$ As shown by Cruickshank ${ }^{25}$ this goal has won hegemony in Norwegian society.

18 Nik Brandal, Øivind Bratberg, and Dag Thorsen, The Nordic Model of Social Democracy (Berlin: Springer, 2013).

19 Rune Slagstad, De nasjonale strateger (Oslo: Pax, 1998).

20 Bjørn Hersoug and Dag Leonardsen, "Bygger de landet," (Oslo: Pax forlag 1979).

21 Valen, "Norway: 'No' to EEC."

22 European Election Database, "Election Results, Sweden: Referendum on the Accession to the European Union, 1994," (2018).

23 "Norway: Referendum on the Accession to the Europen Union 1994," (2018).

24 Håvard Teigen, "Distriktspolitikkens historie: Frå nasjonal strategi til regional fragmentering?," Plan 43, no. 06 (2011).

25 Jørn Cruickshank, "Protest against Centralisation in Norway: The Evolvement of the Goal for Maintaining a Dispersed Settlement Pattern," Norsk Geografisk Tidsskrift - Norwegian fournal of Geography 60, no. 3 (2006). 
From the 1970s, national governments have created various policies to stimulate growth in peripheral areas, especially in Northern Norway. For business development, the most important policy was the introduction of the Regional differentiated payroll taxes (RDP) measure in 1975, based on a series of theoretical studies that discussed the market failures of regional labor markets. ${ }^{26}$ Employers in Norway are levied a payroll tax, which differs between five geographical zones. The highest rate of 14.1 percent is charged in zone 1 , where around 80 percent of the population resides. In the other zones, the rate decreases according to remoteness. In the northernmost regions (Finnmark and Northern Troms) the rate is zero percent. The total national cost of the RDP was estimated to be 13.3 billion NOK in $2016,{ }^{27}$ of which approximately 8 billion NOK was for businesses located in Northern Norway. Regional governments and Innovation Norway have also received money to stimulate regional and business development in Norway. In 2016, one-third of all funds for regional development ( 370 million NOK) went to counties in Northern Norway, despite the fact that only 9 percent of the national population lives in the region.

There is also an extra contribution for municipalities in Northern Norway. The revenue system for Norwegian municipalities is complicated, but the special treatment of Northern Norway is obvious, and the contribution per capita is much higher than for peripheral municipalities further south. In 2017 the total sum of the extra contribution (Nord-Norge tilskot) was around 1.57 billion NOK. ${ }^{28}$ Table 1 displays the net contribution per capita in areas in Northern Norway, compared internally and externally with peripheral areas in the south.

Table 1. Contribution from the national government for regional development.

\begin{tabular}{lcc}
\hline Regions & $\begin{array}{c}\text { Extra contribution } \\
\text { 2017-budget (NOK per capita) }\end{array}$ & $\begin{array}{l}\text { Regional funds 2016-budget } \\
\text { (NOK per capita) }\end{array}$ \\
\hline Nordland and Namdalen & 1710 & 730 \\
Troms (outside special zone) & 3279 & 682 \\
Special zone Troms & 3864 & 682 \\
Finnmark & 8008 & 1087 \\
Peripheral areas in the south & $218-1087^{29}$ & $433^{30}$ \\
\hline
\end{tabular}

26 Arild Hervik and Mette Rye, "An Empirical and Theoretical Perspective on Regional Differentiated Payroll Taxes in Norway," (2003).

27 http://www.statsbudsjettet.no/upload/Statsbudsjett_2017/dokumenter/pdf/skatt.pdf

28 Government of Norway, "Tilskuddsbrev til fylkeskommunene 2016 Programkategori 13.50 Post 60," ed. Ministry of Local Government and Modernisation (2016).

29 Contribution per capita varies depending on the peripheral index for each municipality. There is also a fixed contribution up to 1.2 mill NOK per municipality depending on peripheral status.

30 Average for the counties Hedmark and Oppland. 
Other subsidies at the individual level have also been implemented, such as lower energy taxes that apply only to Northern Norway. Through the creation of the special zone for municipalities in Finnmark and Northern Troms in 1990, people who live in these municipalities benefit from lower income taxes, extra childcare support (until 2014) and student loan write-off schemes. The total sum of individual level incentives for living in the special zone is about 1 billion NOK according to the 2017 national budget. In addition to these major policies, there are also other special arrangements for Northern Norway in smaller policy areas, such as culture, sports and higher education.

The total sum of regional policies aimed primarily at promoting living in Northern Norway was around 12 billion NOK in 2017. All these policies were implemented between 1970 and 1990. Even though they vary in nature, they can be categorized as exogenous growth policies, designed to use fiscal incentives to create growth in lagging areas. ${ }^{31}$

Sweden has also implemented regional policies to promote regional development in lagging regions. ${ }^{32}$ However, the resources used by the government are on a much lower scale than in Norway. For instance, Sweden does provide small tax breaks for companies in lagging regions, but in the period 2000-2006 these tax breaks accounted for about 0.5 billion NOK yearly, ${ }^{33}$ compared to 13.3 billion NOK ( 8 billion in Northern Norway) in 2015. As in Norway, some resources used to promote regional development are also allocated through the County Administrative Boards (länsstyrelser) or to the county or regional councils in Sweden. However, there are not as many specific policies targeting Northern Sweden compared to the Norwegian model, although many of the municipalities that benefit from the Swedish regional policies and transfers within the municipality revenue system are located in the north. The most specific Swedish subsidy that targets the north is a tax deduction for long-distance commuters, ${ }^{34}$ a tax deduction that all long-distance commuters in Norway receive.

Since joining the European Union, Northern Sweden has fallen under the jurisdiction of the EU regional policy, also referred to as the Cohesion Policy. For the period 2014-2020, €207 million was earmarked for the Northern Sparsely Populated Areas, ${ }^{35}$ resulting in an annual contribution to Northern Sweden of around 0.3 billion NOK.

31 Iain Begg, Barry Moore, and John Rhodes, "Economic and Social Change in Urban Britain and the Inner Cities," Critical issues in urban economic development 1 (1986).

32 For a thorough review see Roland Andersson, "The Efficiency of Swedish Regional Policy," The Annals of Regional Science 39, no. 4 (2005).

33 Ibid.

34 Ibid.

35 European Commission, “Cohesion Policy and Sweden,” http://ec.europa.eu/regional_policy/ en/information/publications/factsheets/2014/cohesion-policy-and-sweden. 
Sweden does have a regional policy, but compared to Norway, the difference in scale and resources committed to regional development, especially in the northern areas, is striking.

\subsection{Structure of Municipalities}

The second major policy difference between Northern Norway and Northern Sweden is found in their municipal structure. Sweden conducted a major municipal reform in the 1960s and 1970s, reducing the number of municipalities from around 2000 to 290 . The motivation behind this reform was to ensure that municipalities were capable of producing the necessary services of the new social democratic welfare state. ${ }^{36}$ Francesco Kjellberg describes this process as one of the comprehensive political reforms in western democracies, ${ }^{37}$ leading to a highly different municipal structure in Northern Norway and Northern Sweden (see table 2), despite the fact that Norway implemented a smaller reform in the mid-1960s, reducing the number of municipalities from around 750 to 450 .

Table 2. Municipalities in Northern Norway and Northern Sweden (in 2015).

\begin{tabular}{lcc}
\hline 2015 & Northern Norway & Northern Sweden \\
\hline Number of municipalities & 87 & 29 \\
Number of municipalities $<2000$ & 38 & 0 \\
Number of municipalities $<5000$ & 66 & 9 \\
Largest municipality (population) & 72681 & 120777 \\
Smallest municipality (population) & 486 & 2453 \\
Mean population per municipality & 5525 & 17693 \\
Population median municipality & 2188 & 6771 \\
\hline
\end{tabular}

There are theoretical arguments that claim that smaller jurisdictions lead to more satisfied citizens, ${ }^{38}$ and hence people will not move away. The political economy literature postulates that citizens are more satisfied with smaller jurisdictions because they are more efficient, homogeneous, and democratic. ${ }^{39}$ This perspective argues that local governments offer benefits that citizens appreciate: they facilitate local

36 Lars Strömberg and Jörgen Westerståhl, "De nya kommunerna," in Strömberg, Lars E förgen Westerståhl (red), De nya kommunerna. En sammanfattning av den kommunaldemokratiska forskningsgruppens undersökningar. (Stockholm: Liber Förlag 1983).

37 Francesco Kjellberg, "Local Government and the Welfare State: Reorganization in Scandinavia," in Dente, B. E Kjellberg, F. (red.) The Dynamics of Institutional Change. Local Government Reorganisation in Western Democracies. (London: Sage Publications 1988).

38 Charles M Tiebout, "A Pure Theory of Local Expenditures," Fournal of political economy 64, no. 5 (1956).

39 Poul Erik Mouritzen, “City Size and Citizens' Satisfaction: Two Competing Theories Revisited," European Fournal of Political Research 17, no. 6 (1989); Wallace E Oates, "Fiscal Federalism." (Cheltenham: Edward Elgar Publishing 1999); Tiebout, "A Pure Theory of Local 
adaptions and variations, facilitate citizen influence and participation, and facilitate coordination efficiency. Decentralized governments are said to be more flexible and to have greater ability to adapt to changing circumstances. ${ }^{40}$

These theoretical assumptions about the importance of small municipalities where the needs and desires of the rural population are emphasized are echoed in the works of Ottar Brox on Northern Norway. ${ }^{41} \mathrm{He}$ claims that it is vital to enable and empower local communities in order to generate economic development and population growth. To achieve this goal, problems need to be solved within homogenous local communities, and counter to the development plan for Northern Norway, not within regional structures that mix areas of expansion with sparsely populated areas. ${ }^{42}$ According to Brox, the successful historical development of Northern Norway, compared to Sweden and Scotland, was due to the combination of a large degree of self-determination within smaller local communities and the strong influence of actors from the primary industries in policymaking.

On the other hand, in today's world it is increasingly difficult for smaller municipalities to meet the demands and standards of local government regarding the provision of public services that require a larger scale of production. One of the strategies to cope with these issues is inter-municipal cooperation. According to Hulst and Van Montfort ${ }^{43}$ the joint provision of public services is a way to overcome production-related obstacles and meet the rising expectations of citizens. At the same time, this could mean that the expected advantages, in terms of local adaptations and variations, and citizens' greater influence over policies, are lost. There is little comparative data on the extent of inter-municipal cooperation in Norway, but a report from $2011^{44}$ shows that most inter-municipal cooperation is found in technical areas like ICT, auditing and purchasing, although there are cases of cooperation in other policy areas like environmental protection, business development and emergency preparedness. Though not widespread, inter-municipal cooperation is a potential explanation for the limited effect of preserving smaller municipalities in Norway.

Expenditures."; Harold Wolman, "Decentralization: What It Is and Why We Should Care," Decentralization, Local Governments, and Markets (1990).

40 Gordon L. Clark, "A Theory of Local Autonomy," Annals of the Association of American Geographers 74, no. 2 (1984); Michael Goldsmith and Edward Page, Central and Local Government Relations: A Comparative Analysis of West European Unitary States (Sage London, 1987); David Osborne and Ted Gaebler, "Reinventing Government: How the Entrepreneurial Spirit Is Transforming Government," Reading Mass. Adison Wesley Public Comp (1992); Lawrence J. Sharpe, "Local Government Reorganization: General Theory and Uk Practice," The Dynamics of Institutional Change (1988).

41 Brox, Hva skjer $i$ Nord-Norge?

42 Ibid., 129.

43 Rudie Hulst and André Van Montfort, Inter-Municipal Cooperation in Europe, vol. 238 (Berlin: Springer, 2007).

44 Dag Ingvar Jacobsen et al., "Evaluering av interkommunalt samarbeid etter kommunelovens \27-Omfang, organisering og virkemåte," Universitetet i Agder. Kristiansand (2011). 
A regional economic policy with tax breaks and subsidies has to be kept separate from the question of municipal structure. However, Broxian theories about the salience of small municipalities and national self-determination over primary industries (because of opting out of EU) point in the same direction. The assumption is that smaller Northern Norwegian municipalities should show more positive demographic development compared to municipalities in Northern Sweden. Deriving from the sections above, there are arguments for this hypothesis.

H1: Demographic development has been stronger in smaller municipalities in Northern Norway than in Northern Sweden since 1975.

\subsection{Urbanization, higher education and general theories of development}

Enterprise zone programs, with tax incentives for businesses to promote growth in lagging regions, have been politically popular for decades. Some studies ${ }^{45}$ find a positive effect of Special Economic Zones. More recent studies ${ }^{46}$ show that tax incentivized enterprise zones are not as effective as thought, and do not increase employment. Porter ${ }^{47}$ has emphasized an alternative endogenous approach for regional development, where the need for building and creating localized clusters for economic activity, rather than simply relying on temporary tax breaks or fiscal stimulus packages for attracting exogenous investment, is seen as an alternative strategy for regional development. New Economic Geography theories ${ }^{48}$ focus on core economic agglomerations and urban regions, so-called "spatial spikes", as dominant factors for regional development. Richard Florida ${ }^{49}$ has emphasized the role of cities and the creative class as engines for regional and urban development. Mellander and Florida have analyzed the role of the creative class in Sweden, but mainly focus on larger cities in the south..$^{50}$

45 Stephen Billings, "Do Enterprise Zones Work? An Analysis at the Borders," Public Finance Review 37, no. 1 (2009); Suzanne O'Keefe, "Job Creation in California's Enterprise Zones: A Comparison Using a Propensity Score Matching Model," Fournal of Urban Economics 55, no. 1 (2004).

46 David Neumark and Jed Kolko, "Do Enterprise Zones Create Jobs? Evidence from California's Enterprise Zone Program,” ibid. 68 (2010); Susanne A. Frick, Andrés Rodríguez-Pose, and Michael Wong, "Towards Economically Dynamic Special Economic Zones in Emerging Countries," (Utrecht University, Department of Human Geography and Spatial Planning, Group Economic Geography, 2018).

47 Michael E. Porter, "Location, Competition, and Economic Development: Local Clusters in a Global Economy," Economic development quarterly 14, no. 1 (2000).

48 Steven Brakman, Harry Garretsen, and Charles Van Marrewijk, The New Introduction to Geographical Economics (Cambridge: Cambridge University Press, 2009).

49 Richard Florida, Cities and the Creative Class (Brooklyn: Routledge, 2005).

50 Charlotta Mellander and Richard Florida, "Creativity, Talent, and Regional Wages in Sweden," The Annals of Regional Science 46, no. 3 (2011). 
The establishment of universities also plays a significant role in the production of talent and in population growth. ${ }^{51}$ Norway and Sweden are both countries that have funded, on a national scale, higher education institutions in remote and outlying regions in order to ensure a place for these regions in the modern economy. There are case studies in both Norway ${ }^{52}$ and Sweden ${ }^{53}$ on the regional effect of the establishment of universities in the North. The decision to establish universities in Umeå, Sweden in 1965 and Tromsø, Norway in 1968 was not arbitrary. The intention behind the creation of universities in the North was not only to make higher education available to more people, but also to promote development in these northernmost regions, first in Sweden and then in Norway. ${ }^{54}$ Based on endogenous growth theories that emphasize the role of knowledge cities and urbanization, it is possible to launch a second hypothesis (H2), which does not exclude $\mathrm{H} 1$.

H2: Demographic development has been stronger in university cities in Northern Norway and Northern Sweden compared to other cities in the region.

Finally, it is worth bearing in mind that the Scandinavian welfare model may hold a strong explanatory power for similar development patterns in Norway and Sweden. Esping-Andersen has advanced the importance of the Nordic welfare model ${ }^{55}$ for more social and regional equality. In countries like the Nordic countries with high taxation, universal welfare systems and centralized wage bargaining systems, public goods like kindergarten, education, social services and unemployment benefits are equally distributed through a welfare system where social rights are secured by national law on an individual basis regardless of the place of residence. These comprehensive, universal fundaments of the Nordic welfare state model are essential for explaining why people live in small rural areas in the Scandinavian Arctic region. Universal welfare goods are guaranteed regardless of the size of the municipality. As an example of this so-called "Spatial Keynesianism", a governmental increase in expenditures on unemployment benefits, when unemployment is distributed

51 Peter Arbo and Paul Benneworth, "Understanding the Regional Contribution of Higher Education Institutions: A Literature Review," OECD Education Working Papers, no. 9 (2007).

52 Narve Fulsås, Universitetet $i$ Tromsø 25 år (Universitetet i Tromsø, 1993); Peter Arbo, "Universitetet som regional utviklingsaktør," in Hvor går Nord-Norge? Tidsbilder fra en landsdel $i$ forandring, ed. Svein Jentoft, Jens-Ivar Nergård, and Kjell Arne Røvik (Stamsund: Orkana Akademisk, 2011).

53 Björn Olsson and Ulf Wiberg, Universitetet och den regionala utmaningen (Nora, Bokförlaget nya Doxa, 2003).

54 Lars Elenius et al., The Barents Region: A Transnational History of Subarctic Northern Europe (Oslo: Pax Forlag, 2015).

55 Gosta Esping-Andersen, The Three Worlds of Welfare Capitalism (New York: John Wiley \& Sons, 2013). 


\section{Fonas Stein}

unevenly between regions, channels resources from richer regions to lagging regions. The welfare state is not only a social stabilizer, but also a regional stabilizer. ${ }^{56}$ In this comparative analysis, the welfare system may be an important counter-theory that explains the relative small effect of regional policies.

\section{Methodology}

Although there are perfectly valid arguments for single case studies, there is a tendency for there to be too many of them, especially concerning historical analyses. Kjeldstadli ${ }^{57}$ has argued that historical studies could learn from the social sciences where the comparative method is essential for analyses. There are very few comparative analyses on development in the Arctic regions, although the recent work of Elenius et al..$^{58}$ is an important step in the comparative direction.

The comparative method is not a simple method because it is by no means easy to identify comparable cases. ${ }^{59} \mathrm{By}$ taking the approach of Teune and Przeworski ${ }^{60}$ it is possible to apply the method that they call "most similar systems" design, ${ }^{61}$ which entails finding two cases that are similar in all independent variables except one crucial variable, and then find out if the dependent variable varies between the two cases. Regarding regional development policy in the Arctic region, this pertains to Northern Norway and Northern Sweden.

Comparative research in the social sciences on the Nordic countries is far from new. ${ }^{62}$ However, few analyses on the regional level have been conducted, a phenomenon possibly attributed to what Rokkan ${ }^{63}$ describes as the "whole-nation bias". Traditionally it has been relatively easy to obtain data at the national level,

56 Harvey Armstrong and Jim Taylor, Regional Economics and Policy 3rd Edition (Oxford: Blackwell, 2000).

57 Knut Kjeldstadli, "Nytten av å sammenlikne," Tidsskrift for samfunnsforskning 29, no. 5 (1988).

58 Elenius et al., The Barents Region: A Transnational History of Subarctic Northern Europe.

59 Arend Lijphart, "Ii. The Comparable-Cases Strategy in Comparative Research," Comparative political studies 8, no. 2 (1975).

60 Henry Teune and Adam Przeworski, The Logic of Comparative Social Inquiry (New York: Wiley-Interscience, 1970).

61 See Alexander L. George and Andrew Bennett, Case Studies and Theory Development in the Social Sciences (Boston: MIT Press, 2005). For a broader discussion of various names on comparative analysis.

62 Herbert Hendin, "Suicide and Scandinavia," (New York: Grune \& Stratum 1964); Kaare Svalastoga, Prestige, Class, and Mobility (Stockholm: Scandinavian University Books, 1959); Arthur H. Miller and Ola Listhaug, "Political Parties and Confidence in Government: A Comparison of Norway, Sweden and the United States," British fournal of Political Science 20, no. 3 (1990).

63 Stein Rokkan, Citizens, Elections, Parties: Approaches to the Comparative Study of the Processes of Development (ECPR Press, 2009). 
and comparatively difficult at the subnational level. Northern Norway and Northern Sweden are both geographically located at the same northerly latitude, and both have large capitals in the south, with a difficult infrastructure system on the North-South axis. The settlement structure of both countries was quite similar in the early to mid-20 $0^{\text {th }}$ century, despite differences in scale. During the same period, both countries had Lutheran state churches ${ }^{64}$ and politics were dominated by the Labor (Norway) and Social Democratic (Sweden) parties, especially in the North. ${ }^{65}$ The northern parts of Norway and Sweden also share numerous other social and cultural traits with large homogenous majority populations and small indigenous Sami groups. There is much more that unites these two regions than separates them.

Population growth can be seen as an indicator of regional development. ${ }^{66}$ Even though there are other variables that measure regional development, population growth is used as a proxy variable for development in this paper, especially since the explicit goal of Norwegian policymakers was to maintain the population distribution. Population growth can be measured in absolute or relative terms. The relative growth rate is often more interesting than the absolute growth rate, especially when comparing two regions in two different countries. Relative growth controls for national trends that might impact one of the two countries.

To assess our hypothesis about population development, I have used registry data from the municipal level collected mainly by Statistics Norway and Statistics Sweden. The hierarchical structure of this data allows for comparative analyses of regions at a variety of regional levels, in addition to state-level analyses. To keep the unit of analysis constant throughout the period, the unit of analysis used is the municipality structure of 2013. The dependent variable is defined as a change variable. So, for every municipality we have;

Change $_{\mathrm{t}}=$ percentage of national population $_{\mathrm{t}}-$ percentage of national population ${ }_{\mathrm{t}-1}$.

Even after redefining our dependent variable as a change variable, there is still important autocorrelation in the variance of the models. To deal with this problem, all the models have their error term corrected with an AR1 structure, which more or

64 State and Church are now separate in both countries (as of 2000 in Sweden and 2012 in Norway).

65 Anders Lidström, "Socialdemokraternas tillbakagång 1973-2014: Strukturella förklaringar och regionala variationer," in Forskningsrapporter i statsvetenskap vid Umeå universitet (Umeå: Umeå universitet, 2018).

66 Kristina Vaarst Andersen et al., "Nordic City Regions in the Creative Class Debate-Putting the Creative Class Thesis to a Test," Industry and Innovation 17, no. 2 (2010). 


\section{Fonas Stein}

less removes the autocorrelation. ${ }^{67}$ The models are defined as a panel data analysis. In all models, the variable Year has a random slope for each municipality. There are 116 municipalities based on 64 yearly observations (1952-2015), so the total number of observations is 7424 . This means that every year $t$ is nested within $i$ municipalities. The baseline model (model 0 ) is defined as:

Level 1: $\quad \gamma$ change $_{\mathrm{ti}}=\pi_{0 \mathrm{i}}+\pi_{\mathrm{ii}}$ trend $_{\mathrm{ti}}+\mathrm{e}_{\mathrm{ti}}$

Level 2: $\quad \pi_{0 \mathrm{i}}=\beta_{00}+\mathrm{u}_{0 \mathrm{i}}$

$$
\pi_{1 \mathrm{i}} \text { trend }_{\mathrm{ti}}=\beta_{10}+\mathrm{u}_{\mathrm{ti}}
$$

New models are subsequently built by adding new independent variables. In model 1, an interaction term is modulated for the period 1975-2015 to see if there is any significant change for Norwegian municipalities after implementation of new regional policies and rejection of EU membership. This variable, Year after 1975, is evidently highly correlated with the variable Year (see appendix for correlation matrix for all variables). This small potential problem with multicollinearity does not alter the general fit of the model. Since the aim of this variable is only to control for major changes after 1975, I have included the variables in the models. In model 2 the municipalities are analyzed based on their population size in 1975 (see table 3), to see if there is any difference within categories and to analyze if the effect of Norwegian regional policies is different on various types of municipalities. ${ }^{68}$

Table 3. Municipality categories in Northern Norway and Northern Sweden (in 1975).

\begin{tabular}{lcc}
\hline $\mathbf{1 9 7 5}$ & Northern Norway & Northern Sweden \\
\hline Smallest $(<5000)$ & 62 & 6 \\
Small $(5-9999)$ & 15 & 14 \\
Medium $(10-25000)$ & 7 & 2 \\
Largest $(>25000)$ & 3 & 7 \\
\hline
\end{tabular}

Finally, in model 3 we assess the effects of higher education by creating two dummy variables, one for universities (Tromsø and Umeå) and another one for university colleges based on the year the institutions were founded in these municipalities ${ }^{69} \mathrm{To}$ compare different models, all models are estimated by maximum likelihood procedure (ML). They have also been run with restricted maximum likelihood procedure (REML) showing the same results.

67 Autocorrelation for first lag is -0.06 in the last model.

68 The models were also run with $\log$ (1975-population) as an independent variable. The results are the same as in the reported models, with almost the same level of AIC.

69 Tromsø (1968), Umeå (1965), Bodø (1971), Luleå (1971), Alta (1973), Nesna (1918), Harstad (1994), Kautokeino (1989), Narvik (1994). 


\section{Results}

\subsection{Descriptive statistics}

In figure 1, we see the demographic development in the four categories based on smoothed trend lines. After 1975, in particular, we find some striking similarities.

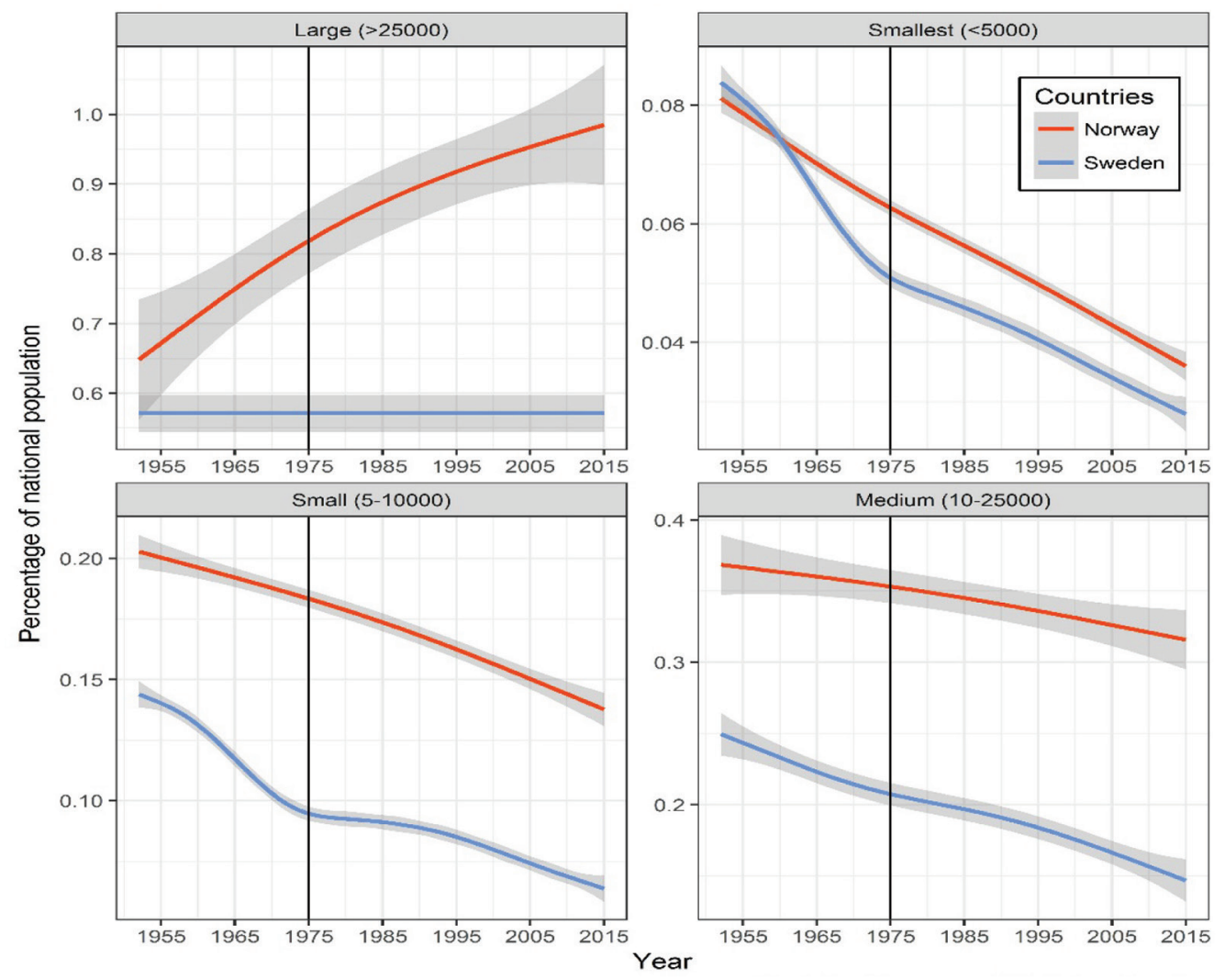

Figure 1. Percentage of national population 1952-2015.

Source: Statistics Norway and Statistics Sweden.

The similar demographic decline seen in figure 1, can also be seen in figure 2, where demographic development in the three largest municipalities in Northern Norway and Northern Sweden respectively is shown in a longitudinal perspective.

\subsection{Regression models}

All models are specified with Year as a random slope for each municipality. In model 0 , there is a small significant negative trend for all municipalities throughout the period. In model 1, this effect is no longer significant when controlling for the interaction in 1975. Here the interaction term for Norway is extremely close to zero and not significant. In model 2 , the category with the largest municipalities is used as a 
The Three Largest Municipalities in Northern Norway and Northern Sweden

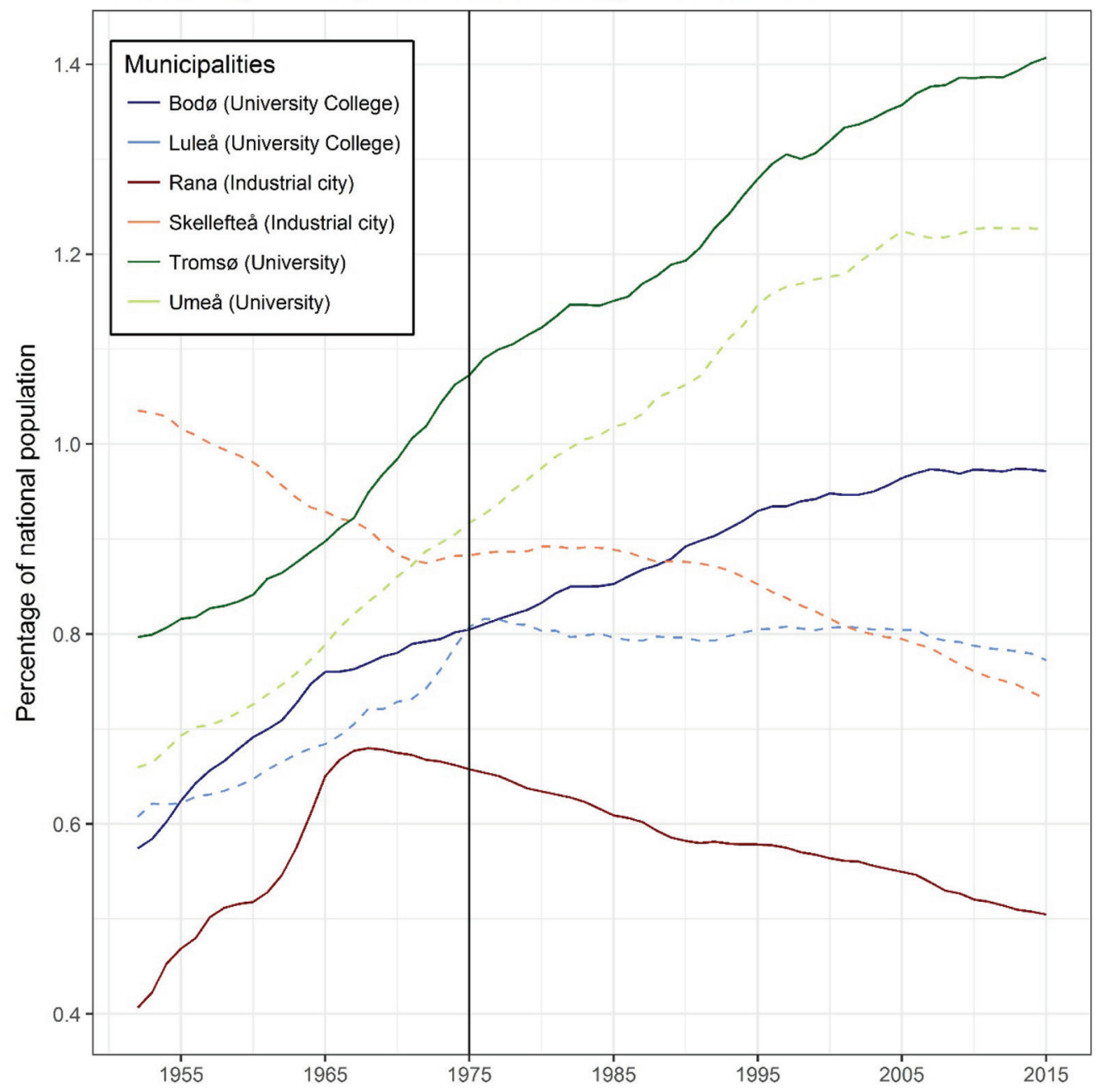

Figure 2. Percentage of national population 1952-2015.

Source: Statistics Norway and Statistics Sweden.

baseline. There is a negative effect for all of the other municipalities compared to the reference category. The interaction between Norway and the other categories of municipalities is significantly negative with a coefficient of -0.004 to -0.005 . However, the total difference between Norway and Sweden is zero due to the dummy variable "Norway" which is significantly positive at 0.005 . This means that demographic development between all the categories, except the largest, is very similar between Northern Norway and Northern Sweden. The relative success of the largest Norwegian municipalities may also be because they are few in number, only three, compared to seven in Sweden. 
Table 4. Multilevel Regression Analysis 1952-2015.

\begin{tabular}{|c|c|c|c|c|}
\hline & \multicolumn{4}{|c|}{ Dependent variable: } \\
\hline & \multicolumn{4}{|c|}{ Yearly change } \\
\hline & Model 0 & Model 1 & Model 2 & Model 3 \\
\hline \multirow[t]{2}{*}{ Year } & $-0.00001^{\star \star \star}$ & -0.00001 & -0.00001 & $-0.00002^{\star}$ \\
\hline & $(0.00000)$ & $(0.00001)$ & $(0.00001)$ & $(0.00001)$ \\
\hline \multirow[t]{2}{*}{ Year after 1975} & & -0.00002 & -0.00002 & -0.00001 \\
\hline & & $(0.00001)$ & $(0.00001)$ & $(0.00002)$ \\
\hline \multirow[t]{2}{*}{ Norway } & & -0.0002 & $0.005^{\star \star \star}$ & $0.002^{\star \star \star}$ \\
\hline & & $(0.0004)$ & $(0.001)$ & $(0.001)$ \\
\hline \multirow[t]{2}{*}{ Municipality $<5000$} & & & -0.001 & $0.002^{\star \star \star}$ \\
\hline & & & $(0.001)$ & $(0.0004)$ \\
\hline \multirow[t]{2}{*}{ Municipality 5000-10000 } & & & $-0.001^{\star}$ & $0.001^{\star \star \star}$ \\
\hline & & & $(0.001)$ & $(0.0003)$ \\
\hline \multirow[t]{2}{*}{ Municipality $10000-25000$} & & & -0.001 & 0.001 \\
\hline & & & $(0.001)$ & $(0.001)$ \\
\hline \multirow[t]{2}{*}{ University city } & & & & $0.009^{\star \star \star}$ \\
\hline & & & & $(0.0005)$ \\
\hline \multirow[t]{2}{*}{ University College city } & & & & $0.001^{\star \star \star}$ \\
\hline & & & & $(0.0003)$ \\
\hline \multirow[t]{2}{*}{ Interaction Norway* Year after 1975} & & 0.00002 & 0.00002 & 0.00002 \\
\hline & & $(0.00001)$ & $(0.00001)$ & $(0.00002)$ \\
\hline \multirow[t]{2}{*}{ Muncipality $<5000^{\star}$ Norway } & & & $-0.005^{\star \star \star}$ & $-0.002^{\star \star \star}$ \\
\hline & & & $(0.001)$ & $(0.001)$ \\
\hline \multirow[t]{2}{*}{ Municipality $5-10000^{\star}$ Norway } & & & $-0.005^{\star \star \star}$ & $-0.003^{\star \star \star}$ \\
\hline & & & $(0.001)$ & $(0.001)$ \\
\hline \multirow[t]{2}{*}{ Municpality $10-25000^{\star}$ Norway } & & & $-0.004^{\star \star \star}$ & $-0.002^{\star \star \star}$ \\
\hline & & & $(0.001)$ & $(0.001)$ \\
\hline \multirow[t]{2}{*}{ Constant } & -0.0002 & -0.0002 & 0.0004 & $-0.001^{\star \star \star}$ \\
\hline & $(0.0002)$ & $(0.0004)$ & $(0.001)$ & $(0.0004)$ \\
\hline Observations & 7,424 & 7,424 & 7,424 & 7,424 \\
\hline Log Likelihood & $36,725.160$ & $36,838.970$ & $36,857.040$ & $36,959.960$ \\
\hline Akaike Inf. Crit. & $-73,440.310$ & $-73,657.940$ & $-73,682.080$ & $-73,883.920$ \\
\hline Bayesian Inf. Crit. & $-73,405.750$ & $-73,588.810$ & $-73,571.480$ & $-73,759.500$ \\
\hline \multirow[t]{2}{*}{ Note: } & & & \multirow{2}{*}{\multicolumn{2}{|c|}{$\begin{array}{l}{ }^{\star} \mathrm{p}<0.1 ;{ }^{\star \star} \mathrm{p}<0.05 ;{ }^{\star \star \star} \mathrm{p}<0.01 \\
\text { Standard errors in parenthesis }\end{array}$}} \\
\hline & & & & \\
\hline
\end{tabular}

Finally, in our last model we test our $\mathrm{H} 2$ and find a relatively large positive effect of having a university, and a smaller, but still significantly positive effect of having a university college. "Knowledge cities" show more positive development than other municipalities. Even though the coefficient is changed in model 3 compared to model 2, the pattern is the same with regards to the relationship between the 
interaction term with population category and Norway. All models show a decreasing AIC and BIC throughout the model building, hence showing that model 3 is the best statistical fit for describing the demographic development in municipalities in Northern Norway and Northern Sweden from 1952 to 2015.

\section{Discussion}

The regression models in Table 4 reject $H 1$. There is no case for arguing that demographic development in smaller municipalities in Northern Norway has been more positive than demographic development in Northern Sweden. The combination of the theoretical framework of Brox, ${ }^{70}$ the implementation of generous regional policies and most importantly the fact that a larger percentage of the national population lives in Northern Norway than in Northern Sweden, makes it understandable why people claim that Norway's regional policies have been successful. Confirmation bias and the notion of state dependency ${ }^{71}$ may lead politicians ${ }^{72}$ and scholars ${ }^{73}$ towards the narrative of a Norwegian success story when analyzing regional policy. The error may also occur because people think cross-sectionally, instead of longitudinally, when analyzing social development. The majority of Norwegian political scientists and sociologists, especially in the $20^{\text {th }}$ century, mainly used cross-sectional analyses instead of longitudinal analyses. ${ }^{74}$ Finally, as mentioned earlier, comparative regional studies are rare in the literature.

The analysis also shows that not all policies for regional development have been in vain. In both countries, policies that have had a significant local and regional impact are not always considered to be policies that promote spatial redistribution, but rather policies that promote social redistribution in line with the Nordic welfare state model. ${ }^{75}$ Public goods like kindergartens, schools, social services and unemployment benefits are equally distributed spatially in the welfare state. Small rural communities are secured a functioning welfare system, and jobs required for welfare production (teachers, nurses, etc.) are also available. Another example is the effect of the national decision to create universities in Umeå and Tromsø to promote social equality by offering higher education to young Swedes and Norwegians in the North. This has also had a strong regional effect. Derived from this, $\mathrm{H} 2$ postulating more positive development in the university cities is confirmed.

70 Brox, Hva skjer $i$ Nord-Norge?

71 Eriksen, "Det nye Nord-Norge: Avhengighet og modernisering i nord."

72 Werner, "Helga satser på by og land"; Vedum, "Sentraliseringen er blåkopi."

73 Paul Pedersen, "Personrettede tiltak som distriktspolitiske virkemiddel i Nord-Troms og Finnmark etter år 2000," in Hvor går Nord-Norge? Bind 3, ed. Svein Jentoft, Jens-Ivar Nergård, and Kjell Arne Røvik (Stamsund: Orkana akademisk, 2013).

74 Tor Midtbø, "Et spørsmål om tid: Tidsserieanalyse som et verktøy i samfunnsvitenskapen," Tidsskrift for samfunnsforskning 41, no. 4 (2000).

75 Esping-Andersen, The Three Worlds of Welfare Capitalism. 
Instead of finding a unique path of regional development in Northern Norway, I have found that Northern Norway and Northern Sweden have experienced a strikingly similar development path over the last 65 years. First, there is a larger trend where a majority of municipalities (105 out of 116) showed negative relative growth in the period 1952-2015. In both countries, universities were established in the 1960 s and 1970s within a social egalitarianism framework to expand opportunities for higher education, develop the Northern regions ${ }^{76}$ and meet the need for highly trained personnel in the expanding health and welfare services sectors in the north. ${ }^{77}$ As seen in the regression model (Table 4) and figure 2, population growth in the two university cities, Umeå and Tromsø, is very similar. These "knowledge cities" seem to be the winners in the Scandinavian North. There is no doubt that the establishment and increased financing of higher education in the Northern regions has been a key policy for national policymakers. When the Norwegian authorities realized that there was not enough capacity in the existing universities in Oslo and Bergen, they decided to meet the expanding need for higher education through the establishment of new universities, despite strong concerns from existing research communities. ${ }^{78}$ Inspired by the establishment of the University of Umeå, the University of Tromsø was also established to promote regional development. The decision to establish a university in Tromsø should be understood as part of the central-peripheral conflict in Norwegian politics. ${ }^{79}$

Second, there are also strong similarities in the relative development between Bodø and Luleå, where national authorities established university colleges in the 1970s, partly as regional investment in industrial activity in the northern part of the country.$^{80}$ The relative success of Tromsø and Bodø (see figure 2) also explains why average growth in the largest municipalities in Northern Norway is so much higher (see figure 1).

Third, the relative decline in the old industrial cities in the High North, especially after 1975, is also striking. Their decline challenges the viewpoint that urbanization is the driving force behind demographic change. Until the early 1970s, Skellefteå was the largest city in Northern Sweden, but it has now been surpassed by Umeå and Luleå. In Northern Norway, Rana's share of the national population has declined since 1970, but a smaller city like Alta, where there is a university college, has increased. The deindustrialization that has marked Western Europe for the last 40 years has also asserted itself in Arctic Scandinavia.

76 Elenius et al., The Barents Region: A Transnational History of Subarctic Northern Europe.

77 Fulsås, Universitetet $i$ Tromsø 25 år; Olsson and Wiberg, Universitetet och den regionala utmaningen; Arbo, "Universitetet som regional utviklingsaktør."

78 Fulsås, Universitetet $i$ Tromsø 25 år.

79 Rokkan, Stat, Nasjon, Klasse.

80 Elenius et al., The Barents Region: A Transnational History of Subarctic Northern Europe. 
Fourth, as seen in the regression models and in figure 1, development after 1975 is very similar for the smallest municipalities, smaller municipalities and medium-sized municipalities, regardless of country. This may partly be explained by the dependence of smaller municipalities on inter-municipal cooperation in order to take advantage of tailor-made policies adapted to local needs. However, the slow but consistent decline over the last 40 years, as predicted by theories of "knowledge cities", 81 urbanization and New Economic Geography ${ }^{82}$, is clear when all municipalities are taken into account, including those with less inter-municipal cooperation. Tiebout ${ }^{83}$ has used the expression "voting with their feet" to describe how people with the freedom to move, choose to live in communities whose local government best satisfies their set of preferences. Comparing Northern Norway and Northern Sweden shows that people in Arctic Scandinavia choose urban locations when they have the choice, not the rural lifestyle envisaged by Brox..$^{84}$ Finally, what do these findings mean for regional policies? Sweden has spent much less than Norway on policies for regional development in the northern parts, but the results are strikingly similar. Future discussions around policies for regional development, should take into account what type of regional policies work instead of focusing solely on the amount of resources applied. Regional development is more than the money spent on regional policies. In order to escape state dependency, actors in peripheral regions should also challenge their perceptions of what is required for development in their region and embrace new ideas for regional development. Putting more and more money into the same structures, like tax subsidies for businesses, does not seem like a good strategy.

Nevertheless, perhaps regional policies should be viewed as a political tool, rather than an economic tool for regional development. This would provide a visible and specific solution to periphery-center misalignment, or as Rokkan puts it, gaining loyalty from the periphery to the center and curbing the center-periphery tension. From this perspective the success of regional policies is not measured by economic or population growth, but by political goals like voting participation or political trust to national institutions. If this is the case, national politicians should reframe the official goals of regional policies.

\section{Conclusion}

Analyzing the long lines of demographic development in Arctic Scandinavia over the last 60 years reveals a striking similarity in development between Northern Norway and Northern Sweden. Despite Norway adopting an expansive regional policy inspired by Broxian theories of growth in smaller municipalities, there is no

81 Florida, Cities and the Creative Class.

82 Brakman, Garretsen, and Van Marrewijk, The New Introduction to Geographical Economics.

83 Tiebout, "A Pure Theory of Local Expenditures."

84 Brox, Hva skjer $i$ Nord-Norge? 
significant effect of these policies regarding demographic development. The larger trend in both countries is that the population in the North has declined at approximately the same relative speed compared to the rest of the nation.

That said, some regionally based policies, like the establishment of universities in the north, seem to have had a positive effect on development. "Knowledge cities" are the drivers for demographic development in Arctic Scandinavia. Establishing regional universities and university colleges has been a deliberate choice by policy-makers partly motivated by a desire to promote regional development. In both countries, this has been the most successful regional development policy in the north.

This study also raises questions about what are the most efficient regional policies. The findings suggest that it is not necessarily the amount of resources applied that matter the most for regional development, and that other factors may be more important. At the same time, the goal of regional policies might be of a more political nature, aiming to curb the center-periphery tension as described by Rokkan.

This study has only focused on the two most similar regions in the Arctic, because of a desire to analyze the specific effect of policies targeted towards Northern Norway. A broader comparative analysis of the whole Arctic region could be a path for further study. Applying a mixed-methodological approach, case studies of some of the smaller, but still relatively successful municipalities in Arctic Scandinavia could also be of interest to social scientists.

\section{ACKNOWLEDGEMENTS}

I am grateful to Marcus Buck, Tor Midtbø and Synnøve Jenssen for highly valuable comments to previous versions of the article. I would also like to thank Sigbjørn Svalestuen for facilitating some of the data used. The publication charges for this article have been funded by a grant from the publication fund of UiT The Arctic University of Norway.

\section{References}

Andersen, Kristina Vaarst, Høgni Kalsø Hansen, Arne Isaksen, and Mika Raunio. "Nordic City Regions in the Creative Class Debate-Putting the Creative Class Thesis to a Test." Industry and Innovation 17, no. 2 (2010/04/01 2010): 215-40.

Andersson, Roland. "The Efficiency of Swedish Regional Policy.” The Annals of Regional Science 39, no. 4 (December 01 2005): 811-32.

Arbo, Peter. "Universitetet som regional utviklingsaktør." In Hvor går Nord-Norge? Tidsbilder fra en landsdel $i$ forandring, edited by Svein Jentoft, Jens-Ivar Nergård and Kjell Arne Røvik. Stamsund: Orkana Akademisk, 2011.

Arbo, Peter, and Paul Benneworth. "Understanding the Regional Contribution of Higher Education Institutions: A Literature Review.” OECD Education Working Papers, no. 9 (2007): 1.

Armstrong, Harvey, and Jim Taylor. Regional Economics and Policy (3rd Edition). Oxford: Blackwell, 2000.

Begg, Iain, Barry Moore, and John Rhodes. "Economic and Social Change in Urban Britain and the Inner Cities." Critical issues in urban economic development 1 (1986): 10-49.

Billings, Stephen. "Do Enterprise Zones Work? An Analysis at the Borders." Public Finance Review 37, no. 1 (2009): 68-93. 


\section{Fonas Stein}

Brakman, Steven, Harry Garretsen, and Charles Van Marrewijk. The New Introduction to Geographical Economics. Cambridge University Press, 2009.

Brandal, Nik, Øivind Bratberg, and Dag Thorsen. The Nordic Model of Social Democracy. Berlin: Springer, 2013. Brox, Ottar. Hva skjer i Nord-Norge?: Oslo: Pax Forl., 1966.

. Nord-Norge: Fra allmenning til koloni. Oslo: Universitetsforlaget, 1984.

Clark, Gordon L. "A Theory of Local Autonomy." Annals of the Association of American Geographers 74, no. 2 (1984): 195-208.

Commission, European. "Cohesion Policy and Sweden.” http://ec.europa.eu/regional_policy/en/information/ publications/factsheets/2014/cohesion-policy-and-sweden.

Cruickshank, Jørn. "Protest against Centralisation in Norway: The Evolvement of the Goal for Maintaining a Dispersed Settlement Pattern.” Norsk Geografisk Tidsskrift - Norwegian fournal of Geography 60, no. 3 (2006/09/01 2006): 179-88.

Database, European Election. "Election Results, Sweden: Referendum on the Accession to the European Union, 1994.” 2018.

. "Norway: Referendum on the Accession to the Europen Union 1994." 2018.

Elenius, Lars, Hallvard Tjelmeland, Maria Lähteenmäki, and Alexey Golubev. The Barents Region: A Transnational History of Subarctic Northern Europe. Oslo: Pax Forlag, 2015.

Eriksen, Erik Oddvar. "Det nye Nord-Norge: Avhengighet og modernisering i nord." In Avhengighet og modernisering $i$ nord, edited by Erik Oddvar Eriksen. Bergen: Fagbokforlaget, 1996.

Esping-Andersen, Gosta. The Three Worlds of Welfare Capitalism. New York: John Wiley \& Sons, 2013.

Florida, Richard. Cities and the Creative Class. London: Routledge, 2005.

Frick, Susanne A., Andrés Rodríguez-Pose, and Michael Wong. "Towards Economically Dynamic Special Economic Zones in Emerging Countries." Utrecht University, Department of Human Geography and Spatial Planning, Group Economic Geography, 2018.

Fulsås, Narve. Universitetet $i$ Tromsø 25 år. Tromsø: Universitetet i Tromsø, 1993.

George, Alexander L., and Andrew Bennett. Case Studies and Theory Development in the Social Sciences. Boston: MIT Press, 2005.

Goldsmith, Michael, and Edward Page. Central and Local Government Relations: A Comparative Analysis of West European Unitary States. Sage London, 1987.

Grønaas, O., J. Halvorsen, and L. Torgersen. "Problemet Nord-Norge." Studieselskapet for nordnorsk neringsliv. (1948).

Hendin, Herbert. "Suicide and Scandinavia." New York: Grune \& Stratum (1964).

Hersoug, Bjørn, and Dag Leonardsen. "Bygger de landet." Oslo: Pax forlag (1979).

Hervik, Arild, and Mette Rye. "An Empirical and Theoretical Perspective on Regional Differentiated Payroll Taxes in Norway.” (2003).

Hirschman, Albert. "Exit, Voice, and Loyalty." Cambridge, MA: Harvard University Press 1 (1970).

Hulst, Rudie, and André Van Montfort. Inter-Municipal Cooperation in Europe. Vol. 238: Springer, 2007.

Jacobsen, Dag Ingvar, E. Kvelland, C. Kiland, and F. S. Gundersen. "Evaluering av interkommunalt samarbeid etter kommunelovens $\ 27-O m f a n g$, organisering og virkemåte.” Universitetet i Agder. Kristiansand (2011).

Kjeldstadli, Knut. "Nytten av å sammenlikne." Tidsskrift for samfunnsforskning 29, no. 5 (1988): 435-48.

Kjellberg, Francesco. "Local Government and the Welfare State: Reorganization in Scandinavia." in Dente, $B$. E Kjellberg, F. (red.) The Dynamics of Institutional Change. Local Government Reorganisation in Western Democracies. London: Sage Publications (1988).

Lidström, Anders. "Socialdemokraternas tillbakagång 1973-2014: Strukturella förklaringar och regionala variationer." In Forskningsrapporter $i$ statsvetenskap vid Umeå universitet, 55. Umeå: Umeå universitet, 2018.

Lijphart, Arend. "Ii. The Comparable-Cases Strategy in Comparative Research." Comparative political studies 8, no. 2 (1975): 158-77.

Mellander, Charlotta, and Richard Florida. "Creativity, Talent, and Regional Wages in Sweden." The Annals of Regional Science 46, no. 3 (2011): 637-60.

Midtbø, Tor. "Et spørsmål om tid: Tidsserieanalyse som et verktøy i samfunnsvitenskapen." Tidsskrift for samfunnsforskning 41, no. 4 (2000): 58-84.

Miller, Arthur H., and Ola Listhaug. "Political Parties and Confidence in Government: A Comparison of Norway, Sweden and the United States." British fournal of Political Science 20, no. 3 (1990): 357-86. 


\section{The Striking Similarities between Northern Norway and Northern Sweden}

Mouritzen, Poul Erik. “City Size and Citizens' Satisfaction: Two Competing Theories Revisited." European Fournal of Political Research 17, no. 6 (1989): 661-88.

Neumark, David, and Jed Kolko. "Do Enterprise Zones Create Jobs? Evidence from California's Enterprise Zone Program.” Fournal of Urban Economics 68, no. 1 (2010): 1-19.

Norway, Government of. "Tilskuddsbrev fil fylkeskommunene 2016 programkategori 13.50 post 60 ." edited by Ministry of Local Government and Modernisation, 2016.

O’Keefe, Suzanne. "Job Creation in California's Enterprise Zones: A Comparison Using a Propensity Score Matching Model." Fournal of Urban Economics 55, no. 1 (2004): 131-50.

Oates, Wallace E. "Fiscal Federalism.” Cheltenham: Edward Elgar Publishing (1999).

Olsson, Björn, and UlfWiberg. Universitetet och den regionala utmaningen. Nora, Bokförlaget nya Doxa, 2003.

Osborne, David, and Ted Gaebler. "Reinventing Government: How the Entrepreneurial Spirit Is Transforming Government.” Reading Mass. Adison Wesley Public Comp (1992).

Parsons, Talcott. "On the Concept of Political Power." Proceedings of the American Philosophical Society 107, no. 3 (1963): 232-62.

Pedersen, Paul. "Personrettede tiltak som distriktspolitiske virkemiddel i Nord-Troms og Finnmark etter år 2000.” In Hvor går Nord-Norge? Bind 3, edited by Svein Jentoft, Jens-Ivar Nergård and Kjell Arne Røvik. Stamsund: Orkana akademisk, 2013.

Porter, Michael E. "Location, Competition, and Economic Development: Local Clusters in a Global Economy." Economic development quarterly 14, no. 1 (2000): 15-34.

Rokkan, Stein. Citizens, Elections, Parties: Approaches to the Comparative Study of the Processes of Development. ECPR Press, 2009.

-. Stat, Nasjon, Klasse. Oslo: Universitetsforlaget, 1987.

- State Formation, Nation-Building, and Mass Politics in Europe: The Theory of Stein Rokkan: Based on His Collected Works. Clarendon Press, 1999.

Rokkan, Stein, and Derek W. Urwin. Economy, Territory, Identity: Politics of West European Peripheries. London: Sage Publications, 1983.

Røvik, Kjell Arne, Jens-Ivar Nergård, and Svein Jentoft. Hvor går Nord-Norge? Stamsund: Orkana akademisk, 2011.

Sartori, Giovanni. “The Sociology of Parties.” In The West European Party System, edited by Peter Mair: Oxford: Oxford University Press on Demand, 1990.

Sharpe, Lawrence J. “Local Government Reorganization: General Theory and UK Practice.” The Dynamics of Institutional Change (1988): 89-129.

Slagstad, Rune. De nasjonale strateger. Oslo: Pax, 1998.

Strøksnes, Morten. "Nordlands profet." Dagbladet, 30.07. 2008.

Strömberg, Lars, and Jörgen Westerståhl. "De nya kommunerna.” $i$ Strömberg, Lars E Förgen Westerståhl (red), De nya kommunerna. En sammanfattning av den kommunaldemokratiska forskningsgruppens undersökningar. Stockholm: Liber Förlag (1983).

Svalastoga, Kaare. Prestige, Class, and Mobility. Stockholm: Scandinavian University Books, 1959.

Teigen, Håvard. "Distriktspolitikkens historie: Frå nasjonal strategi til regional fragmentering?". Plan 43, no. 06 (2011): 48-54.

Teune, Henry, and Adam Przeworski. The Logic of Comparative Social Inquiry. New York: Wiley-Interscience, 1970.

Tiebout, Charles M. “A Pure Theory of Local Expenditures.” fournal of political economy 64, no. 5 (1956): 416-24.

Valen, Henry. “Norway: 'No' to EEC.” Scandinavian Political Studies 8, no. A8 (1973): 214-26.

Vedum, Trygve Slagsvold. "Sentraliseringen er blåkopi.” Nationen, 12.08.2015 2015, 18.

Werner, Kjell. "Helga satser på by og land.” FriFagbevegelse, https://frifagbevegelse.no/article-6.158.52638. bdb95fa 104.

Wilson, James. Bureaucracy: What Government Agencies Do and Why They Do It. New York: Basic Books, 1989.

Wolman, Harold. "Decentralization: What It Is and Why We Should Care." Decentralization, Local Governments, and Markets (1990): 29-42. 
fonas Stein

\section{Appendix: Correlation matrix}

\begin{tabular}{lcccccc}
\hline Variable & Year & Norway & $\begin{array}{c}\text { University } \\
\text { city }\end{array}$ & $\begin{array}{c}\text { University } \\
\text { College city }\end{array}$ & $\begin{array}{c}\text { Year after } \\
1975\end{array}$ & $\begin{array}{c}\text { Municipality } \\
\text { size (numeric) }\end{array}$ \\
\hline Year & 1 & 0 & 0.05 & 0.11 & 0.95 & 0 \\
Norway & 0 & 1 & -0.07 & 0.04 & 0 & -0.05 \\
University city & 0.05 & -0.07 & 1 & -0.02 & 0.03 & -0.21 \\
University College city & 0.11 & 0.04 & -0.02 & 1 & 0.10 & -0.001 \\
Year after 1975 & 0.95 & 0 & 0.03 & 0.10 & 1 & -0 \\
Municipality size (numeric) & 0 & -0.05 & -0.21 & -0.001 & -0 & 1 \\
\hline
\end{tabular}

NB: Coding and data set for this paper are availabe at: https:/github.com/TromsoJonas/ThesisPaper1 